\title{
Macro, Microscopic and Preliminary Analytical Evaluation of Root and Leaf of Globba marantina Linn. - An Extrapharmacopoeial Drug of Ayurveda
}

\author{
S. ROY*, R. N. ACHARYA, C. R. HARISHA ${ }^{1}$ AND V. J. SHUKLA ${ }^{2}$ \\ Department of Dravyaguna, ${ }^{1}$ Pharmacognosy Laboratory, ${ }^{2}$ Pharmaceutical Chemistry Laboratory, Institute for \\ Post Graduate Teaching and Research in Ayurveda, Gujarat Ayurved University, Jamnagar-361 008, India
}

Roy, et al.: Microscopic and Analytical Evaluation of Globba marantina Root and Leaf

\begin{abstract}
Globba marantina Linn., an extra pharmacopoeial plant of Ayurveda, locally known as chhota rasna by tribal people of Orissa, belongs to the family Zingiberaceae. Ethnomedicinally roots and leaves of $G$. marantina is claimed to be used in the management of asthma, rheumatoid arthritis, cough, cold, snakebite and others. Though used traditionally, no proper scientific evaluation of this plant for its pharmacognostical characters has been reported. Hence, the present study has been performed to establish the root and leaf of the plant for its microscopical and physicochemical characters along with different qualitative tests, as per Ayurvedic Pharmacopoeia of India. Powder microscopy of the root shows ample amount of starch grain, prismatic crystal, lignified fiber, scalariform vessel whereas that of leaf shows monocot type III stomata, ample amount of prismatic crystal, fiber and covering trichome. Surface study shows presence of more number of stomata as well as stomatal index, in lower surface, in comparison to upper surface. Physicochemical parameters show higher moisture content in leaf sample $(9.8060 \pm 0.0265 \% \mathrm{w} / \mathrm{w})$ than the root $\operatorname{sample}(9.505 \pm 0.465 \%$ w/w) and water soluble extractive value of both the samples has been found more in comparison to alcohol soluble extractive value. The observed data can be helpful to identify and standardize root and leaf of $G$. marantina.
\end{abstract}

Key words: Chhota rasna, Gndhamardan Hills, Globba marantina, pharmacognostical evaluation, Zingiberaceae

The knowledge about medicinally important plants has been scientifically documented, and systematically presented in Ayurvedic samhitas, nighantus and other texts. Codified information regarding plants of folklore origin has not been documented in the classical texts of Ayurveda. The plants which are not codified in the classical literature of Ayurveda i.e. samhitas or in nighantus but are used traditionally to combat of different diseases are called as anukta dravya (undocumented)/extrapharmacopoeial plants in Ayurveda. These anukta dravyas are the contribution of the studies published through various ethomedicinal/ anthropological survey studies ${ }^{[1]}$.

Globba marantina, Zingiberaceae, an extrapharmacopoeial plant is known as chhota rasna in Orissa and Dancing Girl Ginger in English. It is an erect or inclined herb, leaves oblong to lanceolate attached with sheathing base, inflorescence compact, and flower yellow in colour in the axil of one or more

*Address for correspondence E-mail: sudiptagau@gmail.com of the upper bract. It is found in Eastern Himalayas, West Bengal, Khasia hills, Sri lanka, and Orissa ${ }^{[2-4]}$.

Different parts of $G$. marantina have been claimed ethnomedicinally by traditional practitioners of Orissa in the management of different disease conditions like conjunctivitis, cough, cold, rheumatism, snake bite, asthma, leucoderma and others ${ }^{[2,3]}$. It is also used as spice and eaten as a seasoning in Malaya ${ }^{[4]}$. Inspite of its ethnomedicinal claims, this plant has not been evaluated scientifically, to set standards of pharmacognostical and preliminary phytochemical characters for its proper identification. Hence, this

This is an open access article distributed under terms of the Creative Commons Attribution-NonCommercial-ShareAlike 3.0 License, which allows other the remix, tweak, and build up to the non-commercially, as long as the author is credited and the new creations are licensed under the identical terms.

Accepted 13 July 2016

Revised 02 June 2016

Received 17 June 2015

Indian J Pharm Sci 2016;78(4):469-478 
present study has been carried out to establish its identification and standardization characters through pharmacopoeial parameters.

\section{MATERIALS AND METHODS}

Whole plant of $G$. marantina was collected and identified by the local taxonomist from its natural habitat Paikmal, Orissa, during the months of SeptemberNovember 2014. Then the plant herbarium was authenticated from Botanical Survey of India, Kolkata (Specimen No. SR-01/CHN/Tech.II/2014/108/261). A specimen of the sample herbarium has been deposited in Pharmacognosy Laboratory, Institute for Post Graduate Teaching and Research in Ayurveda, Gujarat Ayurved University (Specimen No. Ph. M: 6143/14/15) (fig. 1a). The roots and leaves were separated and washed with tap water and stored in a solution of $70 \%$ ethyl alcohol:glacial acetic acid:formalin (AAF) in the ratio of (90:5:5) to utilize them for microscopic studies whenever needed ${ }^{[5]}$.

\section{Preparation of plant extract:}

The remaining parts of roots and leaves were dried under the shade. Then dried roots and leaves were powdered individually by mechanical grinder and sieved through 60\# for powder microscopy, physicochemical parameters and qualitative tests. The powder was stored in air tight glass container.

Five gram powder of each sample (root and leaf powder) was macerated with $100 \mathrm{ml}$ water in a closed flask for $24 \mathrm{~h}$, shaking frequently during $6 \mathrm{~h}$ and allowed to stand for $18 \mathrm{~h}$. After $24 \mathrm{~h}$ samples were filtered and water extract was collected. Methanol and chloroform extracts were also prepared following same procedure. All three extracts were used for preliminary phytochemical screening ${ }^{[6]}$.

\section{Morphology:}

Morphological characters of roots and leaves of $G$. marantina were studied as per visual observation, following standard procedure of taxonomy and verified with existing floras for authentication ${ }^{[2,7]}$.

\section{Microscopic evaluation:}

Thin free hand transverse sections of root and leaf (leaf sheathing base and lamina through midrib) of $G$. marantina were taken. Then sections were first observed in distilled water then stained with phloroglucinol (20 $\mathrm{mg} / \mathrm{ml}$ of alcohol) along with hydrochloric acid $(6 \mathrm{~N})$ ferric chloride solution (5\% w/v in $90 \%$ alcohol) and iodine solution ( $2 \mathrm{~g}$ iodine and $3 \mathrm{~g}$ potassium iodide in $100 \mathrm{ml}$ water), respectively and again examined to assess different cellular structure and content. The samples were observed under compound microscope (Quasma, India) and photographs were taken by using Kodak EasyShare C140 HD camera ${ }^{[8,9]}$.

Surface study, micrometric evaluation and organoleptic characters:

Leaf pieces were first cleaned by boiling in choral hydrate solution. Then clear leaf pieces were observed under microscope with distilled water for the determination of vein islet number per sq. $\mathrm{mm}$ and palisade ratio of leaf. For the determination of stomatal index, the upper and lower surface/epidermal layers of clear leaf piece were peeled out separately by means of forceps and kept on slide to mount in glycerin water. The epidermal layer was observed under microscope for the determination of stomatal index and type ${ }^{[10-12]}$. All determinations were performed in triplicate and the results are presented as mean or mean \pm standard error mean (SEM).

Measurement of the length, breath of stomata, crystal, saponin content, trichome was taken into consideration for micrometric evaluation ${ }^{[13]}$ with the help of compound microscope (Quasma, India) and photographs were taken by using Kodak EasyShare C140 HD camera. All determinations were performed in triplicate and the results are presented as mean value.

The colour, odour and taste of both root and leaves were recorded separately through visual and sensory observation $^{[14]}$.

\section{Powder microscopic evaluation:}

Root and leaf powders (60\#) were cleaned individually with chloral hydrate to clear the samples. Then the samples were kept on a slide and studied under microscope using distilled water. The samples were also examined after staining with different suitable reagents i.e. phloroglucinol $(20 \mathrm{mg} / \mathrm{ml}$ of alcohol) along with hydrochloric acid $(6 \mathrm{~N})$, ferric chloride $(5 \%$ $\mathrm{w} / \mathrm{v}$ in $90 \%$ alcohol) and iodine solution ( $2 \mathrm{~g}$ iodine and $3 \mathrm{~g}$ potassium iodide in $100 \mathrm{ml}$ water ${ }^{[14]}$ under compound microscope and photographs were taken by using Kodak EasyShare C140 HD camera.

\section{Physicochemical parameters:}

Assessment of the parameters such as foreign matter, moisture content, ash value, acid insoluble ash, $\mathrm{pH}$, water soluble extractive and alcohol soluble extractive 
were carried out by following standard procedures recommended by Ayurvedic Pharmacopoeia of India and other standard texts ${ }^{[6,15,16]}$. All determinations were performed in triplicate and the results are presented as mean \pm SEM.

\section{RESULTS AND DISCUSSION}

G. marantina is an erect or inclined herb, about 3 feet high with yellow flowers (fig. 1b). The root arises from the short root-stock/node. Single node bears more than 20-30 roots, each about $7.6 \times 0.4 \mathrm{~cm}$ in size. They are all generally long, thick, fleshy, tuberous (resembles Satavari). Roots are gradually tapering towards the basal and distal ends. Outer surface is smooth except for the presence of a few rootlets. The surface skin has been found quite soft and can be easily scraped. On slightly dried roots, the surface appears longitudinally wrinkled and short transverse fissures have been found. Outer portion of roots is yellowish brown in colour. The transversely cut surface of a fresh root shows a creamish coloured inner portion with a silvery white fleshy soft middle region which forms the bulk part of the root. In fresh roots, the creamish coloured outer part can be easily separated from the silvery white part, but adheres firmly in dried roots (fig. 1c). The root possess strong aromatic odour with pungent and slight astringent taste.

Leaves are alternate to spirally arranged, simple, and sessile attached by sheathing base which is about 1.5-2 feet in length, varies as per the arrangement of leaves. Leaves are shaped oblong to lanceolate, margin is slightly wavy with acuminate apex. Leaves are variable

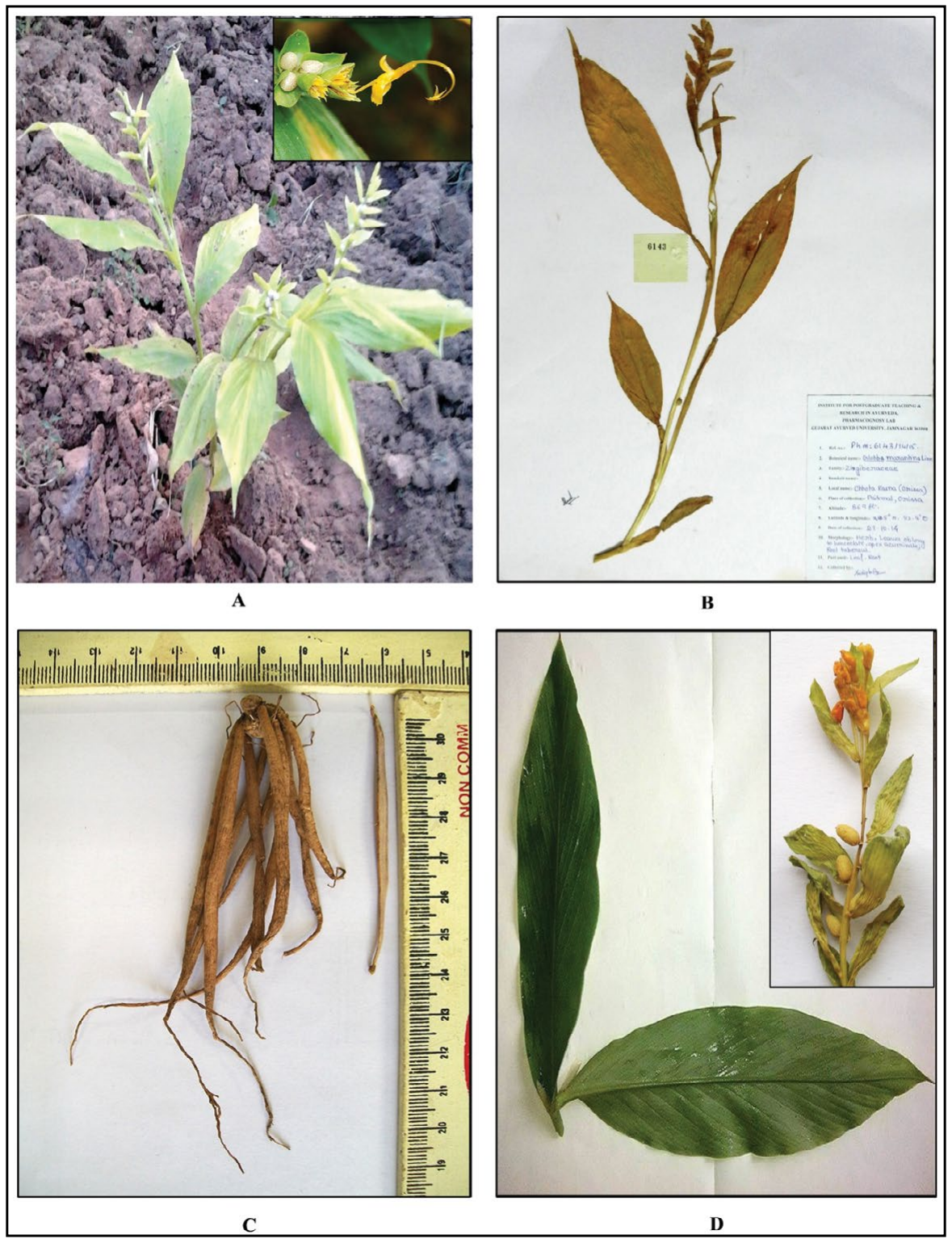

Fig. 1: Morphology of Globba marantina Linn.

(A) whole plant, (B) herbarium (C) measurement of roots, (D) upper and lower surface of leaf and twig with flowers and fruits. 
in size and are $15-18 \mathrm{~cm}$ in length and $3-5 \mathrm{~cm}$ in width. The leaf has parallel venation with a prominent midrib and several oblique secondary veins running parallel to each other (fig. $1 \mathrm{~d}$ ). Upper surface of leaves is darker green in colour in comparison to the lower surface, smooth in touch with no characteristic odour.

Diagrammatic section shows the root is more or less circular in shape. Detailed transverse section shows that outer most layer consists of 8-10 layers of thick walled tangentially elongated cork cells. Outer most cork cells bear piliferous hairs. The cortex occupies the larger area of the section made up of parenchyma cells which are densely filled with simple oval shaped starch grains, oil content and some of the cells are filled with yellowish brown content also. Single layer endodermis followed by cortex, made up of barrel shaped cells forming a ring like structure. Vascular bundles are made up of alternative xylem and phloem components circularly. Xylem consists of metaxylem toward pith, protoxylem toward endodermis covered by xylem parenchyma. Some of the xylem vessels show intraxylary pittings. Phloem alternates the xylem made up of sieve elements and phloem fibers. Adjacent to the xylem, 2-3 layers of pericyclic fibers are present discontinuously all over the circle. Pith is centrally located made up of parenchyma cells loaded by some simple starch grains (fig. 2a-f).

Transverse section of root after staining with suitable

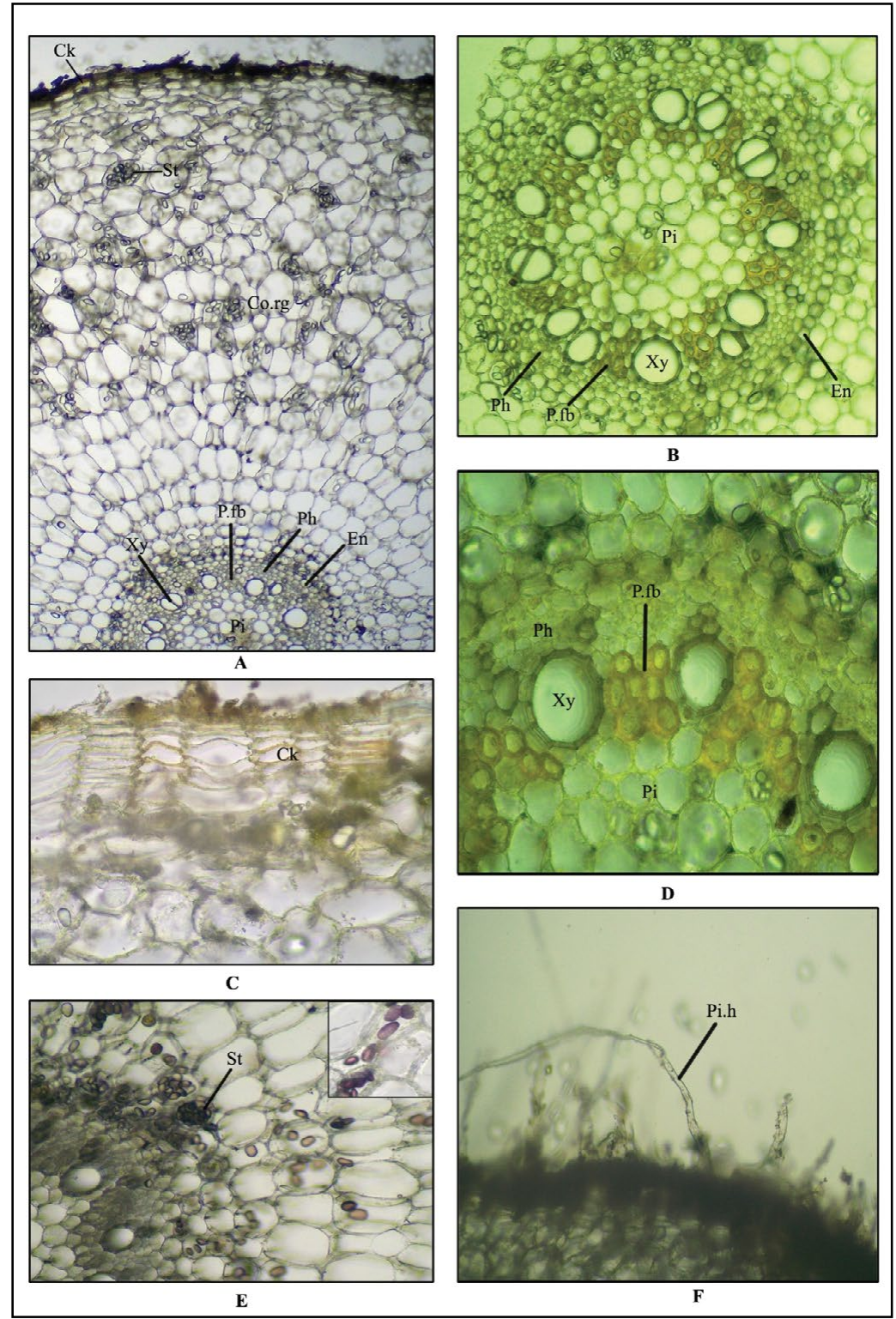

Fig. 2: Microscopic characters of root of Globba marantina Linn.

(A) transverse section of root, (B) stelar region after staining, (C) cork layers, (D) lignified pericyclic fiber after staining, (E) starch grain after staining with iodine solution, (F) piliferous hair; Ck- cork; St- starch grains; Co. rg- cortex region; Xy- xylem; P. fbpericyclic fiber; Ph- phloem; En- endodermis; Pi- pith; Pi.h- piliferous hair. 
reagents shows that the pericyclic fibers are slightly lignified when treated with phloroglucinol along with hydrochloric acid, vascular bundle shows slight bluish black colour after staining with $\mathrm{FeCl}_{3}$, which indicates the presence of slight amount of tannin content in the root. Ample amount of starch grains all over the ground tissue show bluish to purple colour after staining with iodine solution (Table 1).

Diagrammatic section shows that leaf sheathing base is crescent shape in outline (fig. 3). Detailed section of leaf

\section{TABLE 1: RESULTS OF HISTOCHEMICAL TESTS OF GLOBBA MARANTINA ROOT AND LEAF}

\begin{tabular}{|c|c|c|c|c|}
\hline Reagents & Characteristics & Sample & Observation & Result \\
\hline \multirow[t]{2}{*}{ Phloroglucinol+HCl } & Lignified cells & Root & $\begin{array}{l}\text { Pericyclic fiber in T.S and fragment of fiber in powder shows } \\
\text { orange to pink colour }\end{array}$ & + \\
\hline & & Leaf & $\begin{array}{l}\text { Pericyclic fiber in T.S and fragment of fiber in powder orange to } \\
\text { pink colour }\end{array}$ & + \\
\hline \multirow[t]{2}{*}{ lodine solution } & Starch & Root & Formation of bluish to purple colour in powder & + \\
\hline & & Leaf & Formation of bluish to purple colour in powder & + \\
\hline \multirow[t]{2}{*}{$\mathrm{FeCl}_{3}$} & Tannin content & Root & Vascular bundles, trichomes shows slight bluish black colour in T.S & + \\
\hline & & Leaf & $\begin{array}{l}\text { Vascular bundle shows dark bluish black colour in T.S of sheathing } \\
\text { base whereas slight in T.S of midrib through lamina }\end{array}$ & + \\
\hline
\end{tabular}

'+' is positive; '-' is negative
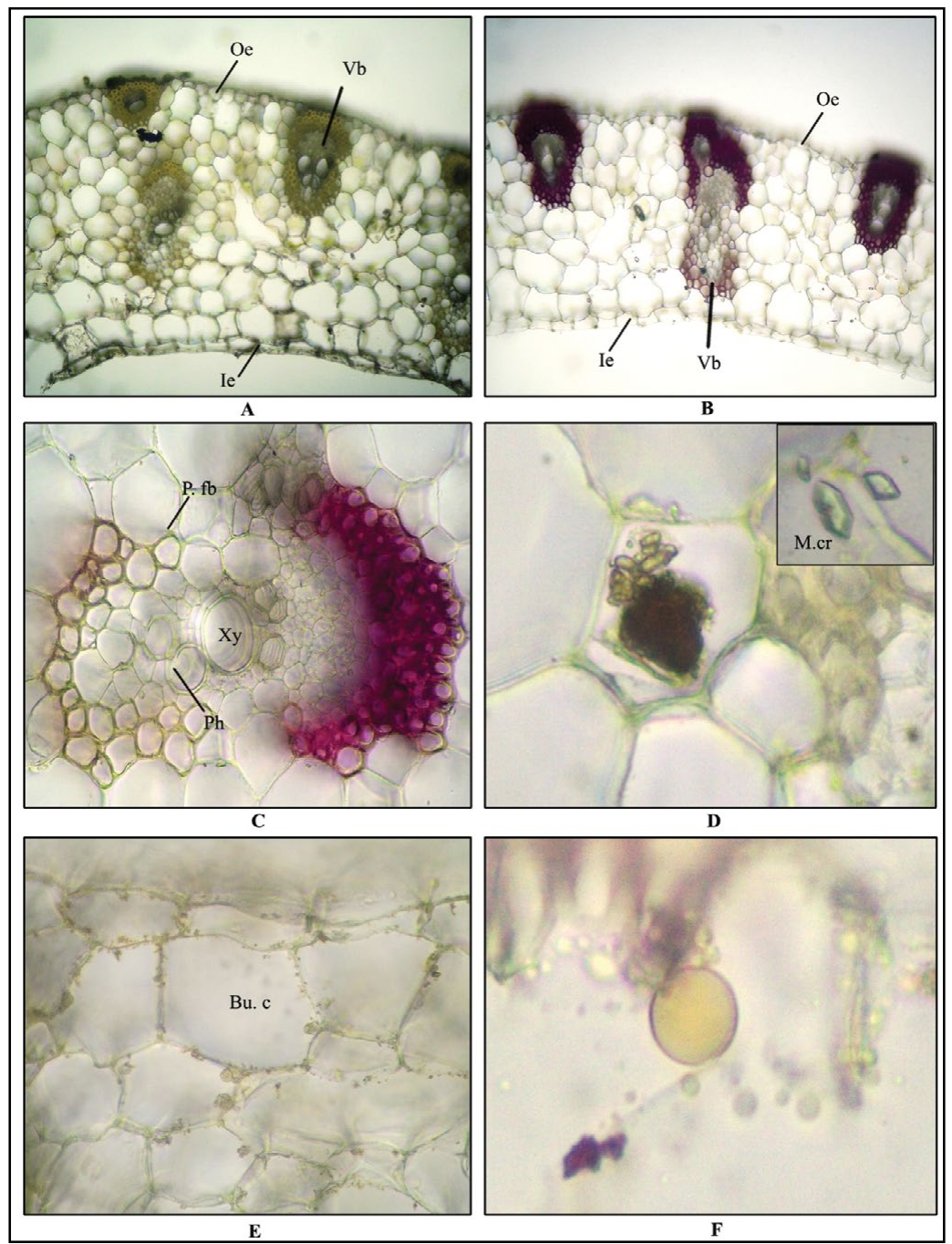

Fig. 3: Microscopic characters of Globba marantina Linn. leaf sheathing base.

(A) transverse section of leaf sheathing base (B) transverse section of leaf sheathing base after staining with phloroglucinol+HCl, (C) lignified pericyclic fiber along with vascular bundle after staining with phloroglucinol+HCl, (D) microcrystal (M. cr) and brown content, (E) bulliform cells of upper epidermis, (F) oil globules; Oe- Outer epidermis; Ie- inner epidermis; Vb- vascular bundle; Xy- xylem; P. fb- pericyclic fiber; Ph- phloem; Bu.c- billiform cell; M. cr- microcrystal. 
sheathing base shows that both outer and inner single layers of epidermis are covered with thin cuticle. Some of the epidermal cells seem to be larger in size known as bulliform cells. Between the epidermis, ground tissue is made up of parenchyma cells with chlorophyll pigments. Some of the ground tissue parenchyma cells consist microcrystals, brown content and oil globules. Vascular bundles are alternatively arranged i.e. two bundles are attached with epidermis and one vascular bundle in between them approximately situated in the middle portion of ground tissue. Vascular bundles closed type with 2-4 xylem vessels and phloem which is made up of phloem fibers and sieve elements forming cap like structure. Vascular bundle surrounded by 3-4 layers of lignified pericyclic fibers. Some of the xylem vessels show intraxylary pittings (fig. 3a-f).

Transverse section of sheathing base after staining with suitable reagents shows that the pericyclic fibers are being lignified after staining with phloroglucinol along with hydrochloric acid, vascular bundle shows slight dark bluish black colour after staining with $\mathrm{FeCl}_{3}$, which indicates the presence of tannin content in the sheathing base (Table 1).

Diagrammatic section shows that upper and lower epidermis consist undifferentiated mesophyll tissue with vascular bundles. Detailed transverse section of midrib with lamina shows that the leaves are isobilateral; the mesophyll tissue is not differentiated properly into palisade and spongy parenchyma. Near the upper epidermal cells, 1-2 layers of parenchyma cells which are somewhat thick walled are densely filled with brown content and oleoresin content. Both sides of this thick walled parenchyma cell layer, loosely arranged cells are found with cells having well developed intercellular spaces among them. The epidermis is found on both upper and lower surfaces of the leaf. Outer wall of epidermal cells is cuticularized. The epidermal layers are uniseriate and composed of more or less oval shaped cells. The upper and lower epidermis may be easily identified due to the presence of bulliform cells, stomatal openings and ample amount of simple, covering trichomes.

Ground tissue of midrib is made up of parenchyma cells which are filled with prismatic crystals of calcium oxalate, most of the parenchyma cells filled with chlorophyll pigments. Some of the vascular bundles are located toward the lower epidermis.

Air chambers and the vascular bundles alternatively arranged towards the lower epidermis. Some of the multicellular glandular trichomes are found in the empty space of air chamber. Vascular bundles are closed type with 1-2 xylem vessels and phloem which is made up of phloem fiber and sieve elements forming cap like structure. Vascular bundles are surrounded by 4-5 layers of lignified pericyclic fibers. Some of the xylem vessels show intraxylary pittings. Isolated groups of vascular bundles are found scattered in the ground tissue (fig. 4a-f).

Transverse section of midrib through lamina after staining with suitable reagents shows that the pericyclic fibers are being lignified after staining with phloroglucinol along with hydrochloric acid, vascular bundle shows slight bluish black colour after staining with $\mathrm{FeCl}_{3}$, which indicates the presence of slight amount tannin content in the midrib (Table 1).

Results obtained from the transverse section of leaf shows that the leaf is isobilateral and the mesophyll is usually not differentiated into palisade and spongy parenchyma but consists only of parenchyma cells, having chloroplasts and intercellular spaces among them. Bulliform cells are also found toward the upper epidermis. These results predominantly represent the characters of monocot plants. Root structure under microscopy also depicts the characters of a monocot family ${ }^{[17]}$.

Both the surfaces consist of monocot type 3 stomata (stoma is surrounded by two subsidiary cells placed lateral to the guard cells). Lower surface shows huge amount of prismatic crystals and saponin containing cells as compared to upper surface (Table 2 and fig. $6 h)$.

Micromeasurements i.e. length and width of stomata, trichome, fiber, crystal, saponin containing cells and vessels of both root and leaf have been taken into consideration (fig. 5b, 5h, 6b and 6d). Then mean value has been calculated and depicted in Table 3.

The powder of G. marantina root is creamish brown in colour, slightly ginger like aromatic in odour and pungent, astringent in taste (fig. 5a). The powder of leaf is yellowish brown in colour with no characteristic odour and pungent, astringent in taste (fig. 6a).

Diagnostic character of root shows fragment of lignified and non-lignified epidermal cell. Silica deposits, covering and simple trichomes, lignified fibers, fragment of parenchyma cells filled with starch grain, brown content, scalariform vessel, ample amount of simple starch grains, oleoresin content (fig. 


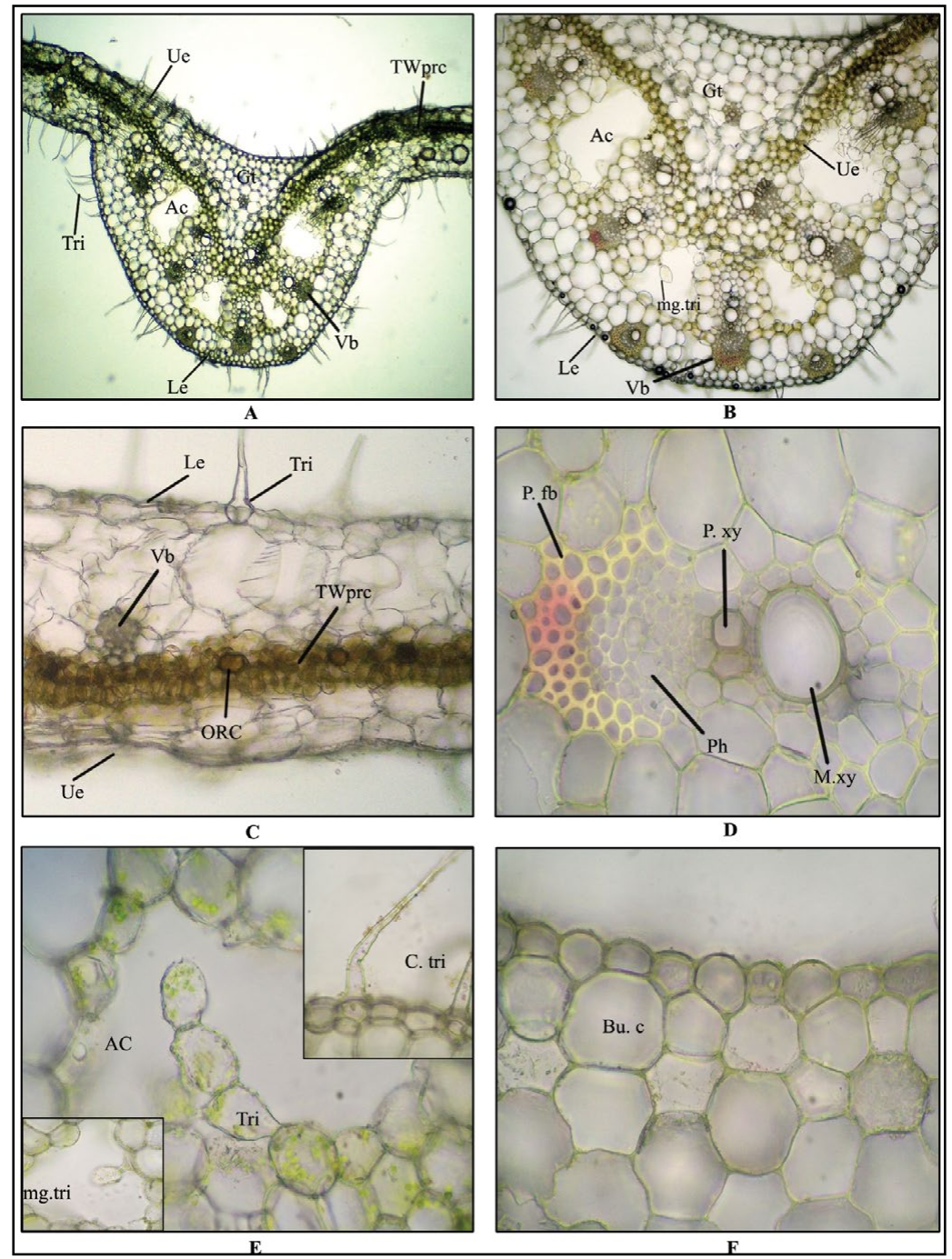

Fig. 4: Microscopy of Globba marantina Linn. midrib through lamina.

(A) transverse section of midrib with lamina, (B) transverse section of midrib after staining, (C) transverse section of lamina, (D) lignified pericyclic fiber along with vascular bundle, $(E)$ trichomes in air chamber and epidermis, (F) bulliform cells. Ue- Upper epidermis; Le- lower epidermis; Tri- trichome; Ac- air chamber; Vb- vascular bundle; Gt- ground tissue; TWprc- thick walled parenchyma; M. xy- metaxylem; P. xy- protoxylem; P. fb- pericyclic fiber; Ph- phloem; ORC- oleoresin content; Bu.c- billiform cell.

5b-h). Diagnostic characters of leaf shows simple and covering trichomes, starch grain, fragment of wavy parenchyma cell, lignified fiber, fragment of epidermal cell, stomata, saponin content, brown content, aleurone grain, annular vessel, silica deposits, prismatic crystal, oil globule, cluster crystal (fig. 6b-g).

Detailed results of physicochemical parameters are given in Table 4. Moisture content has been found more in leaf sample $(9.8060 \pm .0265 \% \mathrm{w} / \mathrm{w})$ in comparison to the root sample $(9.505 \pm 0.465 \% \mathrm{w} / \mathrm{w})$. Foreign matter has not been found in both the samples, which may be due to the good harvesting practice followed during the collection of the drugs. Both ash value and acid insoluble ash have been found to be less in the root sample than the leaf sample, which may signify low level of inorganic matter, sand and silica content in root than the leaf ${ }^{16]}$. Both the sample solutions $(5 \% \mathrm{w} / \mathrm{v})$ show slightly acidic to neutral $\mathrm{pH}$ i.e. 6.47 and 6.57 of root and leaf, respectively. Water soluble extractive in both the samples has been found more in comparision to alcohol soluble extractive value which indicates the probability of the presence of high water soluble constituents than the alcohol soluble in both the samples.

Qualitative tests show the presence of carbohydrate, protein, steroid, terpenoid, alkaloid, tannin and flavonoid in both the samples of leaf and root of $G$. marantina. Results also show that glycoside is absent or may be present in very negligible amount in leaf samples (Table 5).

The data specified in the present study regarding 


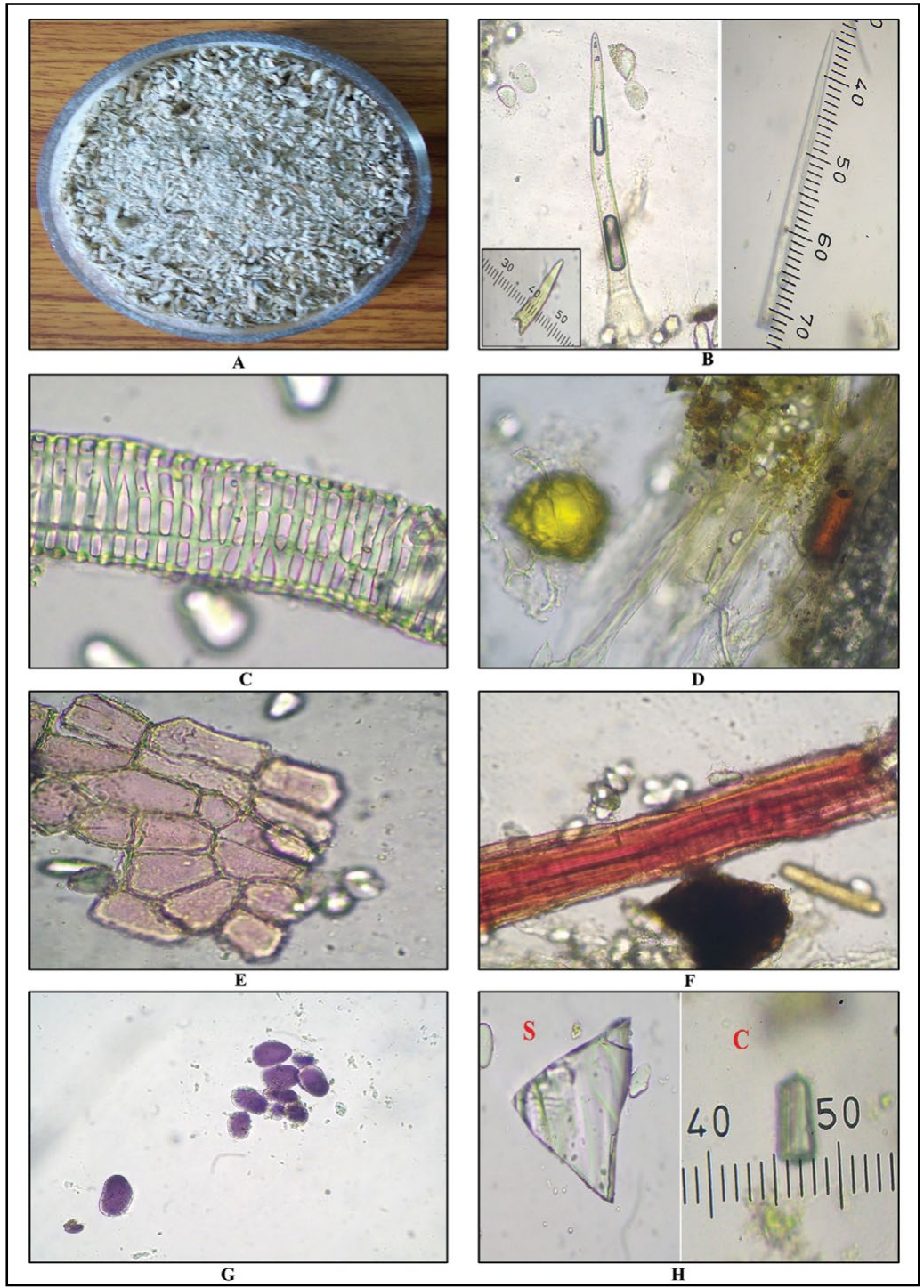

Fig. 5: Powder characters of Globba marantina Linn. root.

(A) powder of root, (B) unicellular and covering trichomes, (C) scalariform vessel, (D) aleurone grain and brown content, (E) lignified fragment of epidermal cell, (F) lignified fiber, (G) starch grain after staining with iodine solution, (H) silica deposits (S) and measurement of crystal.

TABLE 2: SURFACE STUDY OF GLOBBA MARANTINA LINN. LEAF

\begin{tabular}{|c|c|c|c|c|c|c|}
\hline \multirow[t]{3}{*}{ Sample } & \multirow[t]{3}{*}{ Type of stomata } & \multicolumn{4}{|c|}{ Stomatal Index $($ mean $\pm S E M)(n=3)$} & \multirow{3}{*}{$\begin{array}{l}\text { Vein-islet number (per } \\
\text { sq. } \mathrm{mm})(10 \times)\end{array}$} \\
\hline & & \multicolumn{2}{|c|}{ UE per sq. mm } & \multicolumn{2}{|c|}{ LE per sq. mm } & \\
\hline & & $40 x$ & $10 x$ & $40 x$ & $10 x$ & \\
\hline Leaf & Monocot type 3 & $3.505 \pm 0.0650$ & $1.175 \pm 0.0450$ & $9.433 \pm 1.538$ & $15.337 \pm 0.0475$ & $13-18$ \\
\hline
\end{tabular}

SEM=Standard error of mean; UE-upper epidermis; LE-lower epidermis

TABLE 3: MEAN VALUES OF MICROMETRIC EVALUATION OF DIFFERENT CELL AND CONSTITUENTS OF GLOBBA MARANTINA LEAF AND ROOT

\begin{tabular}{|c|c|c|c|c|c|c|c|c|}
\hline \multirow[t]{4}{*}{ Sample } & \multicolumn{8}{|c|}{ Length and Width } \\
\hline & \multicolumn{4}{|c|}{ Stomata } & \multirow[t]{3}{*}{ Crystal (40x) } & \multirow{3}{*}{$\begin{array}{c}\text { Saponin } \\
\text { content cell } \\
(40 x)\end{array}$} & \multirow[t]{3}{*}{ Trichome } & \multirow[t]{3}{*}{ Fiber } \\
\hline & \multicolumn{2}{|c|}{ UE (mm) } & \multicolumn{2}{|c|}{ LE (mm) } & & & & \\
\hline & $40 x$ & $10 x$ & $40 x$ & $10 x$ & & & & \\
\hline Leaf & $\begin{array}{l}\text { L-0.15; } \\
\text { W-0.14 }\end{array}$ & $\begin{array}{l}\text { L-0.04; } \\
\text { W-0.03 }\end{array}$ & $\begin{array}{l}\text { L- } 0.16 ; \\
\text { W- } 0.15\end{array}$ & $\begin{array}{c}\text { L-0.046; } \\
\text { W-0.03 }\end{array}$ & L-0.046; W-0.033 & $\begin{array}{l}\text { L-0.053; } \\
\text { W-0.046 }\end{array}$ & $\begin{array}{l}\text { L-0.64; } \\
\text { W-0.07 }\end{array}$ & L-0.47; W-0.12 \\
\hline Root & Nil & Nil & Nil & Nil & L-0.04; W-0.03 & Nil & L-0.2; W-0.05 & L-0.67; W-0.03 \\
\hline
\end{tabular}

L-length; W-Width; UE-upper epidermis; LE-lower epidermis 


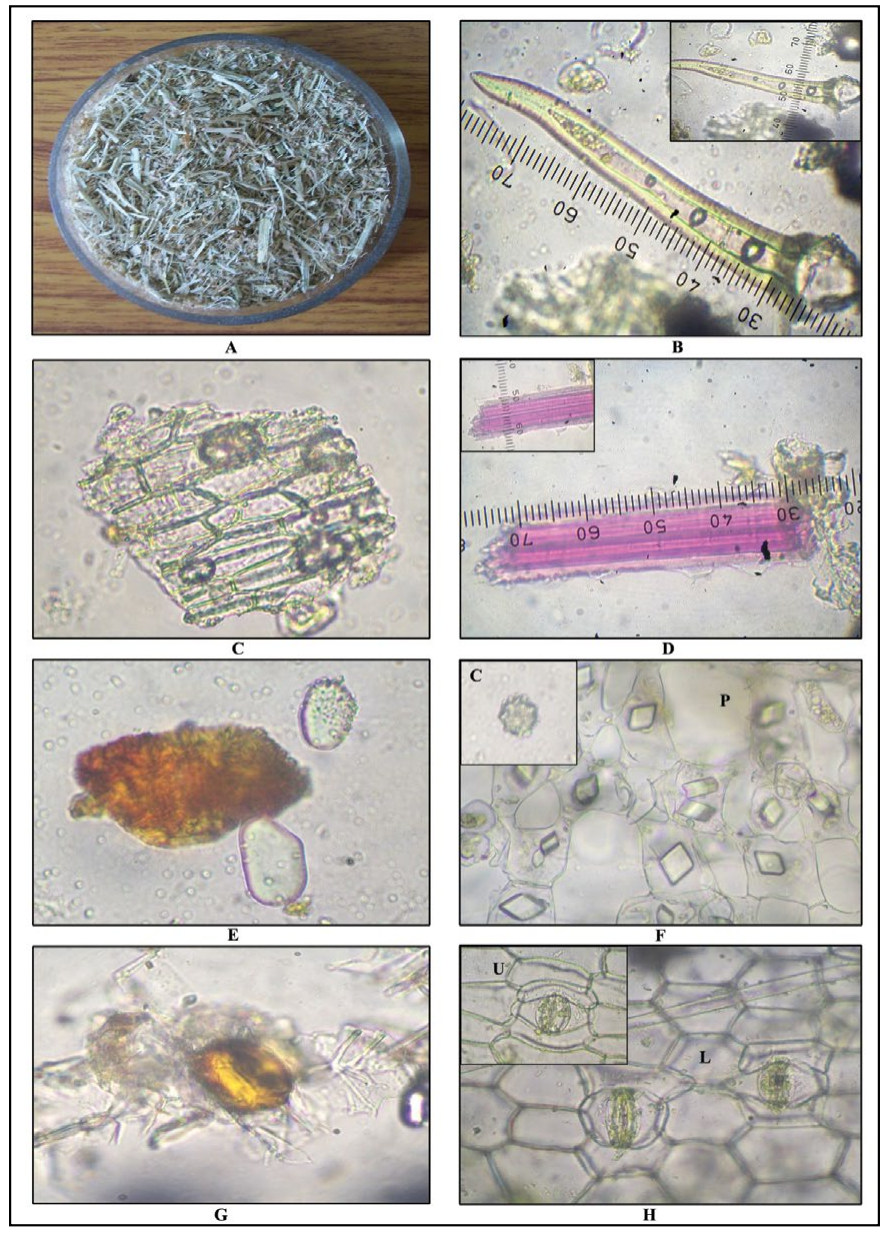

Fig. 6: Powder characters of Globba marantina Linn. leaf.

(A) powder of leaf, (B) measurement of covering trichome, (C) fragment of wavy parenchyma cell, (D) measurement of lignified fiber, (E) brown content, (F) prismatic and cluster crystal, (G) aleurone grain, (H) stomata in upper (U) and lower (L) surfacesurface study.

TABLE 4: VALUES OF PHYSICOCHEMICAL PARAMETERS OF GLOBBA MARANTINA LINN. ROOT AND LEAF

\begin{tabular}{lcc}
\hline Physicochemical parameters & Root & Leaf \\
\hline Foreign matter & Nil & Nil \\
Loss on drying $(\% \mathrm{w} / \mathrm{w})$ & $9.505 \pm 0.465$ & $9.8060 \pm .0265$ \\
Ash value $(\% \mathrm{w} / \mathrm{w})$ & $4.605 \pm 0.615$ & $7.410 \pm 0.420$ \\
Acid insoluble ash $(\% \mathrm{w} / \mathrm{w})$ & $0.518 \pm 0.177$ & $1.131 \pm 0.419$ \\
$\mathrm{pH}(5 \% \mathrm{w} / \mathrm{v})$ & $6.47(\mathrm{RT})$ & $6.57(\mathrm{RT})$ \\
Water soluble extractive value $(\% \mathrm{w} / \mathrm{w})$ & $8.454 \pm 1.284$ & $13.630 \pm 1.210$ \\
Alcohol soluble extractive value $(\% \mathrm{w} / \mathrm{w})$ & $4.284 \pm 0.256$ & $4.416 \pm 1.014$ \\
\hline
\end{tabular}

Valves are given as mean \pm SEM of 3 results $(n=3)$, RT-room temperature; SEM-standard error of mean

TABLE 5: RESULT OF PRELIMINARY QUALITATIVE TESTS OF GLOBBA MARANTINA LINN. ROOT AND LEAF EXTRACT

\begin{tabular}{|c|c|c|c|c|c|c|c|}
\hline \multirow[t]{2}{*}{ Plant metabolite } & \multirow[t]{2}{*}{ Test } & \multicolumn{3}{|c|}{ Root } & \multicolumn{3}{|c|}{ Leaf } \\
\hline & & WE & ME & CE & WE & ME & CE \\
\hline \multirow[t]{3}{*}{ Carbohydrate } & Molisch's test & + & + & - & + & + & - \\
\hline & Fehling's test (for reducing sugar) & + & + & - & - & - & - \\
\hline & lodine test (for starch) & + & - & - & + & - & - \\
\hline \multirow[t]{2}{*}{ Protein } & Biuret test & + & + & - & + & + & - \\
\hline & Ninhydrin test (for Amino acid) & + & + & - & + & + & - \\
\hline Steroid and terpenoid & Salkowski test & + & + & + & + & + & + \\
\hline
\end{tabular}




\begin{tabular}{|c|c|c|c|c|c|c|c|}
\hline \multirow[t]{3}{*}{ Glycoside } & $\begin{array}{l}\text { Borntrager's test (for anthraquinone } \\
\text { glycoside) }\end{array}$ & + & + & - & - & - & - \\
\hline & $\begin{array}{l}\text { Modified Borntrager's test (for } \\
\text { anthraquinone glycoside) }\end{array}$ & + & + & - & - & - & - \\
\hline & Foam test (for saponin glycoside) & + & + & - & - & - & - \\
\hline \multirow[t]{2}{*}{ Flavonoid } & Lead acetate test & + & + & - & + & + & - \\
\hline & Vanilline-HCl test & + & + & - & + & + & - \\
\hline \multirow[t]{2}{*}{ Alkaloid } & Dragendorff's test & - & - & + & - & - & + \\
\hline & Hager's test & - & - & + & - & - & + \\
\hline Tannin & $\mathrm{FeCl}_{3}$ & + & - & - & + & - & - \\
\hline
\end{tabular}

WE: Water extract; ME: methanol extract; CE: chloroform extract; ' + ' is positive; '-’ is negative

morphology and microscopical characters will help for easy identification of the plant G. marantina. Physicochemical and qualitative test reports will help in establishing standards in identity, degree of purity and quality of the plant material as per pharmacopoeial requirements.

\section{Financial support and sponsorship:}

Nil.

\section{Conflicts of interest:}

There are no conflicts of interest.

\section{REFERENCES}

1. Acharya D, Shrivastava A. Indigenous herbal medicines: Tribal Formulations and traditional herbal practices. Jaipur: Aavishkar Publishers Distributor; 2008. p. 440.

2. Saxena HO, Brahmam M. The Flora of Orissa. Vol-III. Bhubaneswar: Orissa Forest Development Corporation Ltd; 1995. p. 1901-2.

3. Anonymous. Reviews on Indian Medicinal Plants. Vol-11. New Delhi: Indian Council of Medical Research; 2013. p886-8.

4. Anonymous. The Wealth of India. Vol IV: F-G. New Delhi: Council of Scientific and Industrial Research; 1956. p. 138.

5. Jothi Prakash EJ. A Text Book of Plant Anatomy. Delhi: Emkay Publication; 2006. p. 225.

6. Anonymous. The Ayurvedic Pharmacopoeia of India, Part- II,
Vol-II. New Delhi: Government of India, Ministry of Health and Family Welfare, Department of AYUSH; 2008. p. 159-61.

7. Ramaswamy SN, Radhakrishna Rao M, Govindappa D. Arekal- Flora of Shimoga District. Karnataka. Mysore: Prasaranga, Manasagangothri; 2001. p. 604.

8. Khandelwal KR. Practical pharmacognosy. 19th ed. Pune: Nirali Prakashan; 2008. p. 9-19.

9. Lohar DR. Protocol for Testing, Ayurvedic, Siddha, Unani medicines, Government of India. Appendix-2. Ghaziabad: Depertment of AYUSH, Ministry of Health and Family Welfare, Pharmacopoeial Laboratory for Indian Medicines; 2007. p. 41-4.

10. Khandelwal KR. Practical Pharmacognosy. 19th ed. Pune: Nirali Prakashan; 2008. p. 146-48.

11. Evans WC. Trease and Evans Pharmacognosy. 16th ed. London: W.B. Sanders company Ltd; 1996. p. 545-6.

12. Wallis TE. Text book of Pharmacognosy. 5th ed. New Delhi: CBS Publishers and Distributors; 2002. p. 113-7.

13. Wallis TE. Text book of Pharmacognosy. 5th ed. New Delhi: CBS Publishers and Distributors; 2002. p. 579.

14. Wallis TE. Text book of Pharmacognosy. 5th ed. New Delhi: CBS Publishers and Distributors; 2002. p. 578-81.

15. Lohar DR. Protocol for Testing, Ayurvedic, Siddha, Unani Medicines, Government of India.Appendix-2. Ghaziabad: Depertment of AYUSH, Ministry of Health and Family Welfare, Pharmacopoeial Laboratory for Indian Medicines; 2007. p. 48-50.

16. World Health Organization. Quality control methods for medicinal plant materials. Geneva: World Health Organization; 1998. p. 15, 35, 40.

17. Pandey BP. Plant Anatomy. New Delhi: S. Chand and Company LTD; 1999. p. 376. 